Н. А. Ясинецька

\title{
ЛІНГВОСТИЛІСТИКА НОВИХ ЗАПОЗИЧЕНИХ АНГЛІЗМІВ В УКРАЇНСЬКІЙ МОВІ
}

Ясинецька Н. А. Лінгвостилістика нових запозичених англізмів в українській мові. У статті систематизавано мовностилістичні особливості англізмів, які виникли й були запозичені до української літературної мови у 1990-х - 2000-х роках: виявлено стилістичні прийоми, когнітивні характеристики, парадигматичні відношення та 
взаємодію стилістичних прийомів у неологізмах-запозиченнях.

Ключові слова: англізм, неологізм, запозичення, стилістичний прийом, парадигматичні відношення.

Ясинецкая Н. А. Лингвостилистика новых заимствованных англицизмов в украинском языке.

В статье систематизированы лингвостилистические особенности англицизмов, которые возникли и были заимствованы украинским литературным языком в 1990-х 2000-х годах: рассмотрены стилистические приёмы, когнитивные характеристики, парадигматические отношения и взаимодействие стилистических приёмов в неологизмах-заимствованиях.

Ключевые слова: англицизм, неологизм, заимствование, стилистический приём, парадигматические отношения.

\section{Ukrainian.}

Yasynetska N. A. Lingual and stylistic peculiarities of new borrowed Anglicisms in

The article outlines the lingual and stylistic peculiarities of Anglicisms that emerged in English and were borrowed to the Ukrainian literary language in the 1990s and 2000s: the revealed features are stylistic devices, cognitive characteristics, paradigmatic relations and stylistic coalescences in the borrowed neologisms.

Key words: Anglicism, neologism, borrowing, stylistic device, paradigmatic relation.

Значний інтерес до сучасних питань неології (Б. М. Ажнюк, Г. М. Віняр, О. Г. Муромцева, О. А. Стишов, О. О. Тараненко та ін.) та запозичення (Л. М. Архипенко, С. П. Денисова, С. А. Карпіловська, Н. О. Попова, В. П. Сімонок, О. А. Стишов та ін.) виявляє в їх основі діалектичний зв'язок мовного розвитку й істотних позамовних чинників, таких як широке використання інтернету з глобалізацією англійської мови [1] та різноплановий розвиток міжнародних відносин в умовах усунення територіально-інформаційної ізольованості країн колишнього радянського блоку. Сучасне мовне оновлення активізувалося під впливом «революції світового павутиння» [4], новітньої «економічної революції» та розвитку електронної торгівлі [3], посилення уваги до загальносвітових екологічних [2] і науковотехнологічних питань, демографічних змін та загалом нових суспільно актуальних явищ [5]. Численні англійськомовні неологізми, які виникли в їх контексті, зафіксовані в лексикографічних працях, зокрема, Г. Барретта, Д. Гріна, Дж. Ейто, П. Макфедріса, Е. Новлз, О. Харгрейвза. Проте сучасні англійсько-українські (англійськоросійські) словники зазвичай містять лише нові комп'ютерні та медійні терміни або надають тлумачення замість перекладу чи форми запозичення та взагалі уникають реєстрування нових англізмів, які інтенсивно засвідчуються як запозичення в українськомовних 
інформаційно-публіцистичних матеріалах.

Об'єктом аналізу у статті є стилістично забарвлені англізми, які виникли й були запозичені до української літературної мови у 1990-х - 2000-х роках; предмет уваги становить їх стилістична функціональність в українській мові. Мета статті - висвітлити різноманіття й мовностилістичні особливості відповідних англізмів під час розв'язання таких завдань: розкрити сутність і причини взаємодії понять «неологізм» та «запозичення»; уточнити умови появи й роль запозичень у формуванні лексико-семантичного складу мовиреципієнта; висвітлити стилістичні прийоми в основі неологізмівзапозичень, їх поєднання та парадигматичні відношення. Актуальність i наукова новизна такого підходу полягають у спробі подолати суперечність між інтенсивним функціонуванням таких англізмів у сучасній українській мові та відсутністю їх закономірної реєстрації в новітніх українськомовних лексикографічних джерелах.

Термін «неологізм» використовуємо на позначення нових слів, лексико-семантичних варіантів слів, словотворчих засобів, фразеологічних одиниць та семантичних варіантів стійких словосполучень, які $є$ новими в обох мовах - англійській та українській. Основними позамовними чинниками оновлення словникового складу мови визнаємо нові політичні, економічні, науково-технічні, культурно-мистецькі умови життя та необхідність передати досягнення, висловити думки й почуття якомога точніше, різнобічніше й логічніше. Головними внутрішньомовними чинниками поповнення словникового складу мови вважаємо «закон економії мовної енергії», унаслідок якого складні синтаксичні структури заміняються єдиним новоутвореним словом, потребу в нових емоційно-експресивних номінатемах i тенденцію до уніфікації та диференціації мовних позначень.

Термін «запозичення» означає як процес засвоєння мовою іншомовних лексичних і фразеологічних одиниць, семантичних значень та словотворчих елементів, так і результат - саме запозичене слово, стійке словосполучення, нове семантичне значення або словотворчий елемент. Такі екстралінгвістичні чинники, як «модність», «престижність», «авторитетність» мови-джерела часто ведуть до невиправданого використання іншомовних лексем. Однак запозичення вважаємо позитивним механізмом у поповненні словникового складу мови-реципієнта, якщо іншомовна лексема використовується для позначення нових понять, явищ $\mathrm{i}$ реалій, задля мовленнєвої 
компактності, для усунення полісемії або омонімії та розмежування смислових відтінків певного значення в мові-реципієнті.

Прагматичний аспект мовлення передбачає використання стилістичних засобів i прийомів для ефективного досягнення комунікативних завдань, влучної реалізації широкого спектру контекстуальних можливостей мовленнєвого впливу та доречного вираження комунікативного смислу висловлювань. Співвідношення логічного й експресивно-оцінного в структурі неологізмів, актуальних для міжмовного запозичення, зумовлює необхідність розуміти під комунікативними потребами суспільства прагнення не лише диференційовано по-новому позначати об'єкти та явища, які виникають у результаті культурних, наукових, громадсько-політичних і суспільнопобутових змін, а й висловлювати оцінку сучасних реалій суспільства, вказуючи на їх подібність, узаємозалежність або суперечливість.

Увага до взаємодії та взаємозалежності когнітивних i номінативних характеристик запозичених до української мови англійськомовних неологізмів межі XX - XXI століть уможливила спостереження за наявністю в них таких лінгвостилістичних прийомів на фонетичному й лексико-семантичному рівнях, як: звуконаслідування, римування, гіпербола, мейозис, алюзія, метафора, метонімія, епітет, оксюморон та іронія.

Звуконаслідування (назва або імітація звуків) у нових англізмах, що адаптуються в українській мові, включає лексеми bang - вибух, beеp - бin, boom - бум/вибуx, burst - вибух, hack - гак/хак на основі метафори (life hacker - лайфгакер «особа, схильна спрощувати життєві ситуації») і метонімії (beeper - біпер «мобільний апарат, який подає сигнали про отримані електронні повідомлення»); адаптації сприяють актуальність тематики їх уживання та міжмовна звукова аналогія. Римування (повторення ідентичних або подібних наголошених складів) зберігається лише в поодиноких випадках (як-от: smart card cмарт-картка «пластикова картка 3 комп'ютерним чипом»).

Гіпербола (перебільшення) та мейозис (применшення) діаметрально протилежно позначають масштабність або якісні ознаки об’єкта чи явища, майже з однаковою частотністю поєднуючись як 3 метафорою (на підставі асоціативної подібності), так і з метонімією (за суміжністю). Наприклад, масштаб зауважують метафоричні неологізми skyscraper ad - рекламний хмарочос «оголошення, розташоване вертикально, збоку багатоповерхової споруди або всієї веб-сторінки» і microblog - мікроблог «невеликий сайт обговорень» та 
метонімічні новоутворення universal release - світовий реліз «випуск аудіо- чи відеопродукції в світових масштабах» і nanoworld-наносвіт «світ мікроскопічних приладів». Ознаки позначають метафори information superhighway - інформаційна супермагістраль «інтернет» $\mathrm{i}$ lipstick indicator - індекс губної помади «схильність купувати маленькі й недорогі приємні речі замість великих і коштовних» та метонімічні англізми cyberaddiction - кіберзалежність «хвороблива залежність від інтернету» i yestertech - вчорашня техніка «застарілі техніка й технології».

У досліджуваних запозиченнях спостерігаємо два типи алюзії (натяку на мовний, літературний, історичний чи суто суспільний елемент або явище): 1) філологічну (weapon of mass distraction - зброя масового відволікання (уваги) (алюзія до словосполучення зброя масового ураження - weapon of mass distruction); 2) соціальну (cold peace - холодний мир «фактично ворожі стосунки без ідеологічного запалу» (алюзія до геополітичної й ідеологічної боротьби (cold war холодна війна) між СРСР і США). В обох випадках алюзії, які поширюються за посередництва ЗМІ, $є$ пов'язаними із соціальноісторичними реаліями, на основі або в контексті яких вони вживаються.

Основними концептуальними рисами, які простежуються в неологізмах-метафорах, є: простір (brand extension, brand stretching розширення бренду «використання імені/марки відомої фірми для популяризації власних товарів»), користь (social mom - соціальна мама «вихователька приватного дитсадка») та шкода (worm - хробак «форма комп'ютерного вірусу»). Різний обсяг стилістичного потенціалу засвідчує відмінні лексико-семантичні типи метафори номінативна (spam - cnам, веб-браузер, cassette - «касета» генів «набір генів»), когнітивна (kangaroo care - метод кенгуру «тримання недоношенного немовляти на грудях у породіллі») та образна (desert storm - буря в пустелі «кодова назва воєнних дій США та їх союзників з НАТО проти Іраку в 1991 році»).

Класифікація нових метонімічних англізмів виявляє 11 моделей наявного в них метонімічного перенесення: «місце - спосіб дії» (17,9\%: cybermeet - віртуальна зустріч (в електронній мережі), «знаряддя - наслідок» (12,8\%: bird flue - nташиний грun, mad pig disease - свинячий сказ, mad cow disease - коров'ячий сказ), «мета наслідок» (12,8\%: fertility tourism - репродуктивний туризм «поїздка за кордон для лікування безпліддя»), «місце - наслідок» (10,3\%: digital 
terrorism - електронний тероризм «маніпулювання електронними зображеннями»), «форма - зміст» (10,3\%: brain gain - приплив мізків «збільшення кількості висококваліфікованих працівників»), «ціле частина/складові» (10,3\%: dot-com - дот-ком, dot-biz - інтернетбізнес «підприємство, яке працює через інтернет»), «зміст - наслідок» (7,7\%: demographic fatigue - демографічна втома «зниження темпів приросту населення»), «причина - наслідок» (7,7\%: famine theft «голодна» крадіжка «крадіжка через надзвичайну бідність») «ім'я суспільне явище» (5,2\%: Generation $O$ - покоління $O$ «покоління виборців Барака Обами в США в 2008 році»), «ім'я - виріб» (2,5\%: Bushism - бушизм «мовна або політична помилка президентів Джорджа Буша старшого чи Джорджа Буша молодшого»), «причина знаряддя» (2,5\%: AIDSline - телефон довіри з ВІЛ/СНІДу, «гаряча лінія» $з$ питань ВІЛ/СНІД). Помітно, що основними різновидами метонімічного перенесення виявилися співвідношення «місце - спосіб дії», «мета - наслідок» і «знаряддя - наслідок», а найменш частотними суміжності «ім'я - виріб» і «причина - знаряддя». Відтак можна зробити висновок, що найактуальнішими питаннями, яких стосуються досліджені нами метонімічні неологізми, є Де? 3 якою метою? Якими засобами? та 3 якими наслідками? функціонує сучасне суспільство 3 його політичними й економічними амбіціями, розвитком науковокомп'ютерних технологій і свободою вибору власного стилю життя.

Неологізми-запозичення 3 компонентом-епітетом засвідчують когнітивне поєднання в них нових ознак з уже відомими за подібністю (метафоричність: golden handcuffs - золоті кайдан(к)u «пільги, які працівник втратить, якщо звільниться 3 компанії») чи суміжністю (метонімічність: crony capitalism - клановий капіталізм «корумпована форма капіталізму»). Концептуальні характеристики епітетів можна об'єднати в 5 основних груп: 1) колір (де чорний, коричневий, сірий, темний позначають прикрі явища; червоний, блакитний, фіолетовий територіально-політичне розмежування; золотий - суспільноекономічні можливості; зелений - екологічну свідомість; а білий - як позитив, так і прикрість: black Tuesday - чорний вівторок «день терактів у Нью-Йорку 11 вересня 2001 року», brownfield - cipa зона, gray hat hacker - сірий гакер, golden rice - золотий рис «різновид генетично модифікованого рису 3 підвищеним вмістом вітаміну А», greentech - «зелена» технологія (екологічно чиста), white hat hacker білий гакер «зламник електронної системи із суспільнокорисною метою», white pollution - біле смітmя «пластикові та паперові 
відходи»); 2) простір (як обмеження, так і їх відсутність: asymmetric(al) warfare, assymetric conflict - асиметрична війна, асиметричний конфлікт «конфлікт з помітно різними можливостями супротивників, через що слабша сторона зазвичай вдається до тероризму», global corporation - глобальна корпоращія «фірма, яка проводить ділові операції в багатьох країнах»); 3) тактильність (температура (cold peace - холодний мир «фактично ворожі стосунки без ідеологічного запалу»), твердість (soft money - «м'які» гроші «нестабільна валюта»), матеріал (velvet divorce - «оксамитове розлучення» «мирний поділ однієї держави на кілька»); 4) свідомість (як інтелектуальна (knowledge sector - інтелектуальний сектор «галузь 3 великою часткою розумової праці»), так i моральна (patriot(ic) hacker - гакер-nampiom «зламник комп'ютерних систем супротивників»); 5) надприродне (міфічність (vampire state держава-вампір «можновладна/корумпована держава») і примарність (phantom fat - прихований жир «жир, не позначений на етикетці»).

Типовими семантико-стилістичними моделями оксюморона (словосполучення здавалося б несумісних понять) $\epsilon$ : власне оксюморон (electronic paper - електронний nanip «тонкий гнучкий аркуш, який містить мікроскопічні частки, які можуть проявлятися як чорні чи білі, реагуючи на електричний заряд»); оксюморон у поєднанні з метафорою (glass wall - скляна стіна «суспільні забобони, які перешкоджають переходити з одного відділу організації в інший»), оксюморона на основі метонімії (blood diamonds - криваві діаманти «діаманти, які добувають в зоні війни, щоб фінансувати купівлю воєнних припасів»), а також оксюморона на основі метафори й метонімії одночасно (soft power - м'яка влада «влада, заснована на непрямому впливові через культурні цінності й ідеологію»).

Для іронії (глузливо-критичного висловлювання) характерними є заснованість на метафорі (pizza parliament - парламентський пиріг «парламент, який складається з багатьох партій/фракцій») й метонімії (втричі частіше; electronic democracy - електронна демократія «використання електронних технологій для зв'язку 3 громадськістю/виборцями»), а також поєднання 3 оксюмороном (glamping (glamour + camping) - глемпінг «туризм 3 використанням дорогого устаткування») та каламбуром (phishing - фішинг (паронімія на основі слова fishing - рибальство) «виманювання в користувачів інтернету їхніх даних, особливо за допомогою створення копії офіційної веб-сторінки банку чи іншої установи»). 
Вияв характеристик оксюморона й іронії може підсилюватися за рахунок гіперболізації шляхом використання так званих «гучних слів» (patriotic hacker - гакер-nampiom). Поєднання оксюморона та іронії спрямоване завуальовано викрити абсурдність явищ, які можуть перерости або вже перетворилися на типові казуси суспільства, що виявляються в самій назві (advertecture (advertisement + architecture) рекламна споруда/архітектура «реклама попереду або на стінах будівель»), в явищі (реер culture - культура підглядання, «підглядання y шпаринку» «суспільство, в якому одні люблять описувати чи показувати своє повсякдення, а інші - читати про це чи спостерігати на екрані»), а також одночасно в назві та явищі (kidult (kid + adult) кідалт «дорослий, що поводиться як дитина»).

Частотним явищем є поєднання стилістичних прийомів. Так, приклад Frankenstein food - «їжа Франкенштейна» (ГМО-продукти вже називають ӥжею Франкенштейна (ТСН.uа, 22.09.2009) засвідчує наявність гіперболи (перебільшення продовольчого жахіття), алюзії (до створення монстра в результаті наукового експерименту молодого вченого Генрі Франкенштейна з класичного науково-фантастичного фільму жахів Джеймса Уейла), метафори (асоціативної подібності генетичних модифікацій до зазначеної істоти), відповідно наявного метафоричного епітета (Frankenstein) і навіть, в англійськомовному варіанті, непрямого звуконаслідування (звукового вираження відрази), який можна простежити в алітерації Frankenstein food.

Типовими проявами парадигматичних відношень в основі нових англізмів-запозичень $\epsilon$ : синонімія (cybermania, cyberaddiction, cybersickness, Internet-mania - кіберманія, кіберзалежність, інтернетхвороба, інтернет(о)манія), антонімія (soft power - м'яка влада «непрямий вплив» та hard power - тверда влада «жорстка політика директивних впливів»), омонімія (WTO - BTO: Всесвітня торгова організація $\neq$ Всесвітня туристична організація), полісемія (електронне сміття - e-waste «(стара) викинута електронна техніка» $\neq$ junk e-mail «рекламне електронне повідомлення») та паронімія (phishing - piшuнt за аналогією до fishing - рибальство).

Увага до взаємозв'язку мовностилістичних та когнітивних характеристик нових англізмів зумовила відповідні висновки. Виявлення умотивованості новоутворень є однією з необхідних умов адекватного розуміння похідної семантики та запозичення актуальних неологізмів. Інформаційно-аналітична публіцистика послуговується запозиченими неологізмами у прагненні оперувати стилістично- 
місткими міжнародно зрозумілими сучасними мовними засобами. У перспективі об'єкт дослідження можуть становити неологізмизапозичення в інших мовленнєвих стилях.

\section{Література}

1. Денисова С. П. Глобалізми та їх адаптація в східнослов'янських мовах / С. П. Денисова // Мовні і концептуальні картини світу : зб. наук. праць. - К. : Видавничо-поліграфічний центр «Київський університет», 2007. - С. 220-226.

2. Зацний Ю. А. Екологічні проблеми сьогодення й інноваційні процеси / Ю. А. Зацний, Е. Г. Балюга // Вісник СумДУ. - 2003. - № 4 (50). - С. 79-82.

3. Campbell K. The Business English at Work : People, Skills, Language / Katherine Campbell. - London : BBC World Service, 2001. -50 p.

4. DiSessa A. A. Changing Minds. Computers, Learning and Literacy / Andrea A. diSessa. - Cambridge : The MIT Press, 2000. - 271 p.

5. Newman K. S. A Different Shade of Gray Midlife and Beyond in the Inner City / Katherine S. Newman. - N.Y. : New Press, 2003. -306 p. 